\title{
Korelasi Konsentrasi Kalsium Serum dengan Fungsi Paru pada Remaja di Makassar
}

\author{
Ermida Sumardi ${ }^{1}$ Arif Santoso ${ }^{2}$ Andriany Qanitha ${ }^{3}$ \\ ${ }^{1}$ Jurusan Fisiologi Program Studi Biomedik Sekolah Pascasarjana, Universitas Hasanuddin, \\ Makassar, 90245 \\ ${ }^{2}$ Bagian Respirasi Program Studi Biomedik Universitas Hasanuddin, Makassar, 90245 \\ ${ }^{3}$ Bagian Infection Center RSUP Dr Wahidin Sudirohusodo Makassar, 90245 \\ Email: ermidasumardi28@gmail.com
}

\begin{abstract}
Abstrak. Penelitian ini bertujuan untuk mngetahui korelasi antara konsentrasi kalsium serum dengan fungsi paru pada remaja di SMA Sanur Makassar. Desain penelitian yang digunakan adalah cross sectional study. Populasi dan sampel dalam penelitian ini adalah remaja di SMA Sanur Makassar. Pengumpulan data menggunakan data primer dan data sekunder. Data dianalisis menggunakan analisis univariat dan bivariat. Hasil penelitian menunjukkan bahwa responden paling banyak adalah dengan konsentrasi kalsium serum $>9 \mathrm{mg} / \mathrm{dl}$ yaitu $66,67 \%$, dan memiliki fungsi paru (KV) normal yaitu 73,68\%, demikian dengan fungsi paru (KVP) normal yaitu 75,44\%. Hasil uji statistik diperoleh nilai signifikansi 0,423 >0,05, dan nilai F hitung 0,651 < F tabel 2,55, maka disimpulkan bahwa ada korelasi secara signifikan antara konsentrasi kalsium serum dengan fungsi paru (KV).
\end{abstract}

Kata kunci: Korelasi, kalsium serum, fungsi paru.

\section{Correlation of Serum Calcium Concentration with Lung Function Adolescents in Makassar}

\begin{abstract}
This study aims to determine the correlation between serum calcium concentration and lung function in adolescents at Sanur Makassar High School. The research design used was cross sectional study. The population and sample in this study were teenagers at Sanur Makassar High School. Data collection uses primary data and secondary data. Data were analyzed using univariate and bivariate analysis. The results showed that the most respondents were with serum calcium concentrations $>9 \mathrm{mg} / \mathrm{dl}$ that is $66.67 \%$, and had normal lung function (KV) which was $73.68 \%$, so with normal lung function (KVP) which was $75.44 \%$. Statistical test results obtained a significance value of $0.423>0.05$, and a calculated $\mathrm{F}$ value of $0.651<\mathrm{F}$ table 2.55 , it was concluded that there was a significant correlation between serum calcium concentration and pulmonary function (CV).
\end{abstract}

Keywords: Correlation, serum calcium, pulmonary function.

\section{PENDAHULUAN}

Pertumbuhan paru dimulai sejak fase anak sampai usia sekitar 22 tahun atau 24 tahun. Seiring dengan bertambahnya usia seseorang, secara normal juga akan terjadi perubahan nilai fungsi paru yang secara statis (menetap) sampai usia 30 tahun akan mengalami penurunan secara perlahan (gradual) (Sholihah, 2015).
Salah satu yang penting dalam menentukan fungsi paru yaitu kapasitas vital, yang mencerminkan daya elastisitas organ paru dan kekuatan pergerakan dinding thoraks. Nilai kapasitas vital dipengaruhi oleh anatomi tubuh, kekuatan otot-otot pernafasan, daya compliance paru dan posisi tubuh pada saat pengukuran fungsi paru. Pada pria dewasa kapasitas paru-parunya 
cenderung lebih besar $(20-25 \%)$ dibanding pada wanita. Kekuatan otot antara pria dan wanita juga berbeda. Pada wanita dewasa muda kapasitas vital kurang lebih 3,1 liter, sedangkan pada pria dewasa muda sekitar 4,6 liter. Orang yang memiliki postur tubuh yang tinggi kurus memiliki kapasitas vital paru lebih besar dibandingkan dengan orang yang pendek dan gemuk. Orang yang melakukan latihan (olahraga) rutin dapat meningkatkan kapasitas vital paru sekitar $30-40 \%$ dari normal (Guyton \& Hall, 2013). Selain kekuatan otot pernafasan, berat badan dan tinggi badan juga mempengaruhi nilai fungsi paru (Sahat, 2011).

Paru-paru sebagai organ pernafasan melaksanakan proses respirasi dimulai dari menghirup udara dari luar (atmosfir) masuk ke sistim pernafasan selanjutnya akan bercampur dengan darah. Terdapat nutrisi dan oksigen di dalam darah termasuk diantaranya kalsium dan kalium yang berfungsi untuk mendukung kerja saraf. Demikian juga dengan otot pernafasan yang bekerja untuk mempertahankan ventilasi paru (Arifatuzzahro \& Anam, 2019).

Selain dibutuhkan untuk pembentukan tulang dan gigi, kalsium yang merupakan mineral penting tubuh juga berfungsi untuk menunjang kerja otot, memelihara otot dan syaraf dalam tubuh agar dapat berfungsi secara normal (Dewajanti et al., 2017). Untuk melakukan potensial aksi, mempertahankan massa otot dan meningkatkan kerja otot diperlukan peranan ion kalsium (Guyton \& Hall, 2013).

Seiring bertambahnya usia, absorbs kalsium juga akan semakin menurun. Anak usia 1 sampai 10 tahun absorbs kalsium sekitar $75 \%$, remaja $40 \%$, usia dewasa muda 20 - 35 tahun sekitar $20-30 \%$. Usia anak dan remaja lebih banyak membutuhkan kalsium 2-4 kali dibanding orang dewasa untuk mendukung kebutuhan pertumbuhan mereka. Untuk memenuhi kebutuhan tubuh, kalsium disimpan sebagai cadangan di dalam tulang (Valentina et al., 2014).

\section{Penelitian tentang kalsium}

khususnya yang berhubungan dengan saluran pernapasan masih sangat sedikit, beberapa penelitian epidemiologi menunjukkan adanya hubungan kekurangan vitamin D dan kalsium dengan berbagai penyakit paru seperti penyakit paru obstruktif kronis, fibrosis kistik, infeksi pada saluran napas dan serangan asma (Rompies, 2016).

Berdasarkan latar belakang diatas maka tubuh sudah seharusnya perlu mendapatkan asupan yang seimbang agar dapat membantu proses absorpsi kalsium dari saluran cerna yang kemudian dapat digunakan sebagai pengatur regulasi sel dan aktivitas otot, termasuk otot-otot pernafasan yang pada akhirnya berdampak pada perubahan faal pada paru, Berdasarkan hal tersebut maka penelitian ini bertujuan untuk mengetahui lebih lanjut mengenai korelasi antara konsentrasi kalsium serum dengan fungsi paru pada remaja di SMA Sanur Makassar.

\section{METODE PENELITIAN}

Desain penelitian yang digunakan adalah cross sectional study untuk menganalisis hubungan variabel independen terhadap variabel dependen dengan pengukuran sesaat secara bersamaan dan pengambilan datanya dilakukan pada tempat yang sama, kondisi yang sama dan tanpa dikendalikan (Sugiyono, 2017). Populasi dalam penelitian ini adalah remaja di SMA Sanur Makassar. Sampel dalam penelitian ini adalah remaja di SMA Sanur Makassar yang memenuhi kriteria penelitian yaitu 57 responden. Teknik pengumpulan data dilakukan 
menggunakan data primer dan data sekunder. Analisis data dilakukan menggunakan analisis univariat dan bivariat.

\section{HASIL}

Tabel 1 menunjukkan, rata-rata umur responden dalam penelitian ini adalah 17 tahun $\pm 1,01$, paling banyak adalah laki-laki yaitu $37(64,9)$ responden, dengan IMT sebagian besar normal yaitu $39(68,4)$. Sedangkan nilai rata-rata konsentrasi kalsium serum adalah 110,01 $\pm 1,17$, fungsi paru (KV) 85,67 $\pm 10,94$, dan fungsi (KVP) 90,14 $\pm 15,82$.

\section{Tabel 1. Karakterstik Umum Responden}

\begin{tabular}{ll}
\hline Karakteristik & Frekuensi $^{*}$ \\
\hline Umur (Tahun) & $17,03 \pm 1,01$ \\
Jenis Kelamin: & \\
Laki-laki & $37(64,9)$ \\
Perempuan & $20(35, .1)$ \\
IMT: & \\
Normal & $39(68,4)$ \\
Kurang & $17(29,8)$ \\
Lebih & $1(1,8)$ \\
Kalsium Serum (mg/dl) & $10,01 \pm 1,17$ \\
Kalsium Serum (Kategorik): & \\
$\leq 9$ mg/dl & $19(33,3)$ \\
$>9$ mg/dl & $38(66,7)$ \\
Fungsi Paru: & \\
KV & $85,67 \pm 10,94$ \\
KVP & $90,14 \pm 15,82$ \\
Fungsi Paru KV (kategorik): & \\
Normal & $42(73,7)$ \\
Restriksi & $15(26,3)$ \\
Fungsi Paru KVP (kategorik): & \\
Normal & $43(75,4)$ \\
Restriksi & $14(24,6)$ \\
Jumlah & $\mathbf{5 7}(\mathbf{1 0 0 , 0})$ \\
\hline N (\%), Mean+SD, N=57 &
\end{tabular}

Tabel 2 menunjukkan, responden dengan konsentrasi kalsium $\leq 9 \mathrm{mg} / \mathrm{dl}$ berjumlah $19 \quad(33,3 \%)$ responden, 11 (19,3\%) memiliki fungsi paru (KV) normal dan $8 \quad(14,0 \%)$ mengalami gangguan fungsi paru (KV) restriksi. Sedangkan responden dengan konsestrasi kalsium serum $>9 \mathrm{mg} / \mathrm{dl}$ berjumlah 38 $(66,7 \%)$ responden, $31(54,4 \%)$ memiliki fungsi paru (KV) normal dan 7 (12,3\%) mengalami gangguan fungsi paru (KV) restriksi.
Tabel 2. Tabulasi Konsentrasi Kalsium Serum Dengan Fungsi Paru (KV) Pada Responden di SMA Sanur Makassar

\begin{tabular}{cccc}
\hline \multirow{2}{*}{$\begin{array}{c}\text { Konsentrasi Kalsium } \\
\text { Serum }\end{array}$} & \multicolumn{2}{c}{ Fungsi Paru (KV) } & Total \\
\cline { 2 - 3 } & Normal & Gangg. Restriksi & \\
\hline$\leq 9 \mathrm{mg} / \mathrm{dl}$ & $11(19,3)$ & $8(14,0)$ & $19(33,3)$ \\
$>9 \mathrm{mg} / \mathrm{dl}$ & $31(54,4)$ & $7(12,3)$ & $38(66,7)$ \\
\hline Total & $42(73,3)$ & $15(26,3)$ & $57(100,0)$ \\
\hline Sumber: Data Primer & & &
\end{tabular}

Grafik 1 menunjukkan hasil uji Linearitas Grafik Scatter Plot, terlihat titik-titik plot data membentuk pola garis lurus dari kiri bawah naik ke kanan atas. Hal ini menunjukkan adanya hubungan yang linear dan positif antara konsentrasi kalsium serum dengan fungsi paru (KV). Hal ini dibuktikan pada uji Signifikansi Deviation From Linearity, diperoleh nilai signifikansi $0,423>0,05$, dan nilai $\mathrm{F}$ hitung $0,651<\mathrm{F}$ tabel 2,55.

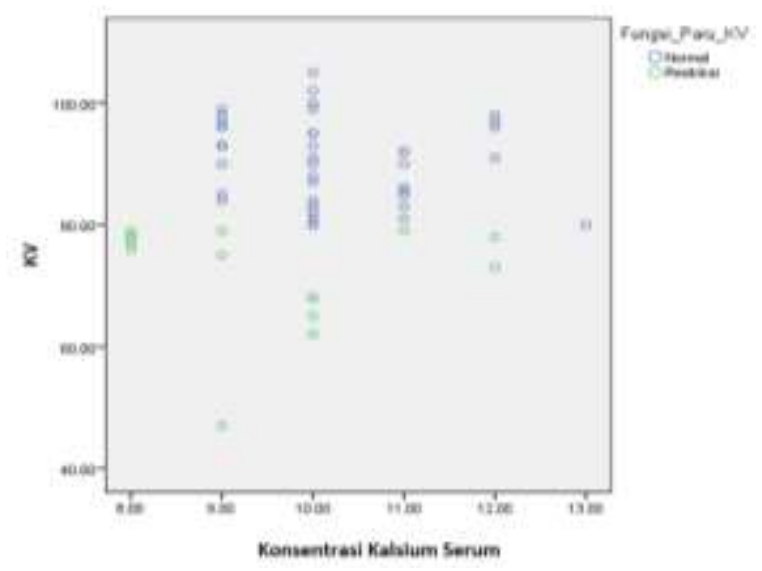

Grafik 1. Korelasi Antara Konsentrasi Kalsium Serum Dengan Fungsi Paru (KV) Pada Responden di SMA Sanur Makassar

\section{PEMBAHASAN}

Kalsium merupakan salah satu mineral yang sangat penting dan diperlukan untuk membantu pertumbuhan tulang, selain itu kalsium juga berfungsi untuk menunjang kerja otot, memelihara otot dan syaraf dalam tubuh agar dapat berfungsi secara normal (Dewajanti et al., 2017). Untuk melakukan potensial aksi, 
mempertahankan massa otot dan meningkatkan kerja otot diperlukan peranan ion kalsium (Guyton \& Hall, 2013).

Perubahan kadar kalsium dalam CES menyebabkan sistim saraf akan menjadi semakin peka (penurunan ion kalsium menyebabkan permeabilitas membran saraf terhadap ion natrium meningkat) (Sherwood, 2018).

Konsentrasi kalsium dalam serum rata-rata mendekati $9,4 \mathrm{mg} / \mathrm{dl}$, normalnya bervariasi antara 9 dan $10 \mathrm{mg} / \mathrm{dl}$. Kadar ini kira-kira setara dengan 2,4 $\mathrm{mmol}$ kalsium per liter. Kadar kalsium serum diatur oleh Hormon Paratiroid (Sherwood, 2018).

Paru-paru terletak pada rongga dada, berbentuk kerucut yang ujungnya berada di atas tulang iga pertama dan dasarnya berada pada diafragma (Guyton \& Hall, 2013). Fungsi utama paru-paru untuk pertukaran gas antara darah dan atmosfer. Pertukaran gas tersebut bertujuan untuk menyediakan oksigen bagi jaringan dan mengeluarkan karbon dioksida. Kebutuhan oksigen dan karbon dioksida terus berubah sesuai dengan tingkat aktivitas dan metabolisme seseorang, tapi pernafasan harus tetap dapat memelihara kandungan oksigen dan karbon dioksida tersebut (West, 2014).

Salah satu hal penting dalam menentukan fungsi paru yaitu kapasitas vital, yang mencerminkan daya elastisitas organ paru dan kekuatan pergerakan dinding thoraks. Nilai kapasitas vital dipengaruhi oleh anatomi tubuh, kekuatan otot-otot pernafasan, daya compliance paru dan posisi tubuh pada saat pengukuran fungsi paru. Pada pria dewasa kapasitas paru-parunya cenderung lebih besar $(20-25 \%)$ dibanding pada wanita. Kekuatan otot antara pria dan wanita juga berbeda. Pada wanita dewasa muda kapasitas vital kurang lebih 3,1 liter, sedangkan pada pria dewasa muda sekitar 4,6 liter. Orang yang memiliki postur tubuh yang tinggi kurus memiliki kapasitas vital paru lebih besar dibandingkan dengan orang yang pendek dan gemuk. Orang yang melakukan latihan (olahraga) rutin dapat meningkatkan kapasitas vital paru sekitar $30-40 \%$ dari normal (Guyton \& Hall, 2013). Selain kekuatan otot pernafasan, berat badan dan tinggi badan juga mempengaruhi nilai fungsi paru (Sahat, 2011).

Paru-paru sebagai organ pernafasan melaksanakan proses respirasi dimulai dari menghirup udara dari luar (atmosfir) masuk ke sistim pernafasan selanjutnya akan bercampur dengan darah. Demikian juga dengan otot pernafasan yang bekerja untuk mempertahankan ventilasi paru (Arifatuzzahro \& Anam, 2019).

Dalam proses metabolisme tubuh, kalsium berfungsi menghubungkan kerja saraf, jantung, mineralisasi tulang, koagulasi darah serta berperan untuk menjaga integritas dan permeabilitas membrane (Yildirim et al., 2018). Kalsium juga memiliki peran penting sebagai second messenger di intra sel dalam regulasi sel. Keseimbangan kalsium di intra sel dalam regulasi sel diatur dengan cara terjadinya ikatan antara kalsium dan protein EF - kalmodulin yang mengaktivasi sel sehingga akan meningkatkan kalsium bebas di intrasel (sitosol) seratus kali. Peningkatan kalsium menyebabkan transduksi sinyal yang berbeda terhadap berbagai aktivitas sel, demikian pula pada aktivitas otot pernafasan (Kurniawan, 2016).

Sel membutuhkan kalsium untuk mengaktifkan enzim tertentu, transportasi ion melintasi membran sel, dan mengirim dan menerima pesan antar sel saraf. Kalsium juga sebagai elektrolit yang berperan dalam menjaga detak jantung teratur. Jika seseorang tidak mendapatkan kalsium yang cukup dari 
makanan yang dimakannya, tubuh akan mengambil kalsium dalam tulang untuk menjaga fungsi sel agar tetap normal, dimana akan menyebabkan kelemahan pada tulang (Veratamala, 2019).

\section{SIMPULAN}

Mengacu pada hasil penelitian, disimpulkan bahwa responden paling banyak adalah dengan konsentrasi kalsium serum $>9 \mathrm{mg} / \mathrm{dl}$ yaitu $66,67 \%$, dan memiliki fungsi paru (KV) normal yaitu $73,68 \%$, demikian dengan fungsi paru (KVP) normal yaitu 75,44\%. Hasil uji statistik diperoleh nilai signifikansi $0,423>0,05$, dan nilai $\mathrm{F}$ hitung $0,651<\mathrm{F}$ tabel 2,55, maka disimpulkan bahwa ada korelasi secara signifikan antara konsentrasi kalsium serum dengan fungsi paru (KV).

\section{DAFTAR PUSTAKA}

Arifatuzzahro, \& Anam, M. Perbedaan nilai fungsi paru pada anak asma saat tidak terjadi serangan dan tidak asma; 2019. 8(1), 38-45.

Dewajanti, A. M., Rumiati, F., Pengajar, S., Biokimia, B., \& Fisiologi, B. (2017). Peran Kalsium dalam Penurunan Berat Badan pada Obesitas.

Guyton, \& Hall. (2013). Buku Ajar Fisiologi Kedokteran.

Kurniawan, S. N. Intracellular Ca2+ Homeostasis; 2016.MNJ (Malang Neurology Journal), 1(1), 36-45. https://doi.org/10.21776/ub.mnj.201 5.001.01.7

Rompies, R. Hubungan antara kadar kalsium dengan serangan asma pada anak; 2016. Jurnal Biomedik, 8, 179183.

Sahat, C. S. Peningkatan Kekuatan Otot Pernapasan Dan Fungsi Paru Melalui Senam Asma Pada Pasien
Asma; 2011. Jurnal Keperawatan Indonesia, 14, 101-106.

Sherwood, L. (2018). Fisiologi Manusia dari Sel Ke Sistem Edisi 8 (9th ed.). EGC.

Sholihah, M. Studi Faal Paru Dan Kebiasaan Merokok Pada Pekerja Yang Terpapar Debu Pada Perusahaan Konstruksi Di Surabaya; 2015. The Indonesian Journal Of Occupational Safety And Health, 4, 1-10.

Sugiyono. (2017). Statistika Untuk Penelitian. Alfabeta.

Valentina, V., Valentina, V., Sri, N., \& Andarwulan, N. Asupan Kalsium Dan Vitamin D Pada Anak Indonesia Usia 2 - 12 Asupan Kalsium dan Vitamin D pada Anak Indonesia Usia 2 - 12 Tahun [ Calcium and Vitamin D Intake of Indonesian Children 2-12 Years Old ]; 2014.

June. https://doi.org/10.6066/jtip.2014.25. 1.83

Veratamala, A. (2019). Parenting Nutrisi Anak.

West. (2014). Interaction Of Energy And Bovine. Dairy Sci.

Yildirim, M. E. C., İsmayılzade, M., Dadaci, M., \& Ince, B. Vitamin D and Systemic Effects of Vitamin D Deficiency; 2018. Selcuk Tip Dergisi, $2(34)$,

84-89. https://doi.org/10.30733/std.2018.01 052 